\title{
Work in deregulated labour markets: a research agenda for precariousness
}

Valeria Pulignano

Working Paper 2019.03 



\section{Work in deregulated labour markets: a research agenda for precariousness}

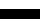

Valeria Pulignano

Working Paper 2019.03

european trade union institute 
Valeria Pulignano is a professor of sociology at the Centre for Sociological Research, KU Leuven (Belgium). Her research broadly covers industrial and employment relations and labour markets in Europe, considered from a comparative perspective. She is Co-President of the Research Network17 on 'Work, Employment and Industrial Relations' within the European Sociological Association and Chief Editor of the stream on 'Work, Employment and Organizations within Frontiers in Sociology'. She is Associate Fellow at the Industrial Relations Research Unit (Warwick University) and co-researcher at the Interuniversity Research Centre on Globalization and Work (CRIMT) at the University of Montreal and the University of Laval (Canada). Her most recent book, written with Virginia Doellgast and Nathan Lillie, is Reconstructing Solidarity. Labor Unions, Precarious Work and the Politics of Institutional Change in Europe, Oxford University Press (2018).

ETUI publications are published to elicit comment and to encourage debate. The views expressed are those of the author(s) alone and do not necessarily represent the views of the ETUI nor those of the members of its general assembly.

Brussels, 2019

- Publisher: ETUI aisbl, Brussels

All rights reserved

Print: ETUI Printshop, Brussels

D/2019/10.574/04

ISSN: $1994-4446$ (print version)

ISSN: 1994-4454 (electronic version)

The ETUI is financially supported by the European Union. The European Union is not responsible for any use made of the information contained in this publication. 


\section{Contents}

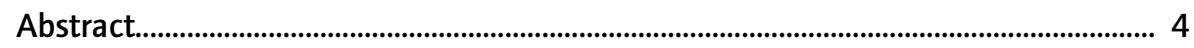

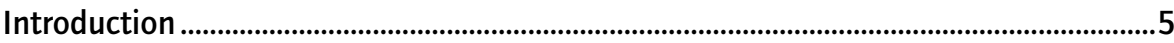

Researching the micro-foundations of precariousness

within the continuum of paid and unpaid work .................................................................

Three case studies of unpaid work ……….................................................................... 10

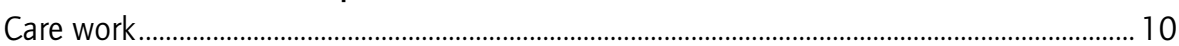

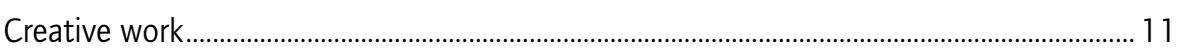

Digital work

A heuristic framework for precariousness within the continuum of paid and unpaid work ....................................................................................................... 14

Workers without work: implications for the workers' voice and trade unions ............18

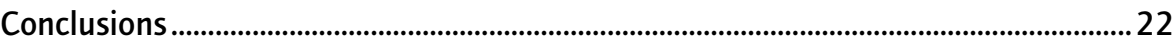

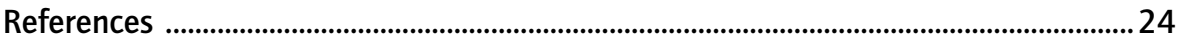




\section{Abstract}

The traditional dichotomy of paid versus unpaid work has a tendency to marginalise unpaid work when we attempt to conceptualise precariousness, leading to our perception that it involves exposure to the unpredictability of an individual's future. A new theoretical and empirical perspective is thus required - one that breaks with the distinction between paid and unpaid work and rethinks precariousness in terms of the paid-unpaid continuum of work by identifying the unpaid activities that increasingly underlie paid employment as a source of 'value' creation in a deregulated labour market. This paper proposes an original heuristic analytical framework for the study of precariousness within the continuum of paid and unpaid work, while presenting its features, explaining the various underlying motives and shedding light on its scientific and policyrelated dimensions. 


\section{Introduction}

This working paper poses two fundamental questions: what counts as work within a deregulated labour market; and what are the implications for the study of precariousness? We draw on evidence from existing work arrangements, within formal (paid) employment relationships, in order to develop a heuristic analytical framework for assessing precariousness in relation to both paid and unpaid work activities.

Unpaid work is defined here as unremunerated work within formal (paid) employment. Accordingly, unpaid work reflects changes occurring in today's labour markets. We postulate that assessing the social implications of unpaid work on individuals' lives seeks to overcome the traditional categorical dichotomy between paid (productive) and unpaid (reproductive) work. Changes in the domain of both paid and unpaid work corroborate this hypothesis. On the one hand, paid work today is less secure, and people can lose their jobs at any time because of company restructuring or closure, without those jobs necessarily being contractually 'temporary' (Weil, 2014). On the other hand, unpaid work has gradually lost its original purpose of being solely concerned with social reproduction. For example, under 'work-first' labour market policies, people must now take up unpaid (or low-paid) jobs (i.e. zero-hour contracts) or face losing their social benefits. Furthermore, new technology (e.g. the introduction of digital platforms) and the emergence of new business models (e.g. outsourcing, partnerships, spin-offs) have led to new ways of organising and coordinating work, across the wide range of paid and unpaid activities that are performed within the remit of (paid) employment. We contend that both paid and unpaid activities should be taken into account when considering precariousness in the current context of deregulated labour markets.

Commodification lies at the core of the traditional sociological understanding of paid work. Accordingly, paid work is valued by the remuneration it generates. For example, the OECD considers income as one of the main aspects of job quality and satisfaction. Nevertheless, the value and the quality of work cannot be reduced to income alone, since work encompasses various features of individuals' lives (Conen and De Beer, 2013). On the other hand, the growth in the fragmentation of jobs and the unbundling of tasks within current deregulated labour markets have increased the dispersion of work activities, which have become 'invisible' (Crain et al., 2016). Studies in sociology have referred to 'invisible' and 'shadow' work as unpaid work (Illich, 1981; Craig, 2015). Unpaid work can apply to a wide range of both material (i.e. transformative) and immaterial (i.e. involving social status, individual aspirations, feelings) work practices generating significant profits to 
society (Hochschild, 1983). Additionally, as a result of precariousness being the alternative to unemployment (Rubery et al., 2018), people for whom the receipt of benefits is contingent on their actively seeking work and their willingness to accept available jobs with reduced social protection (Dörre, 2015; Pulignano, 2018) may be those at greater risk of undertaking unpaid work. In general, this highlights the importance of taking unpaid work as a mainly sociological concept into account in the study of labour markets and employment relations in order to assess the extent to which and how it contributes to precariousness in today's capitalist society. This is the primary focus of this working paper.

Despite extensive recent research which has assessed the conditions of precarious work (Standing, 2009; Vosko, 2010; Kalleberg, 2010; Rubery et al., 2016; Doellgast et al., 2018; Vallas, 2012) and reported on the growing amount of unpaid work that is often undertaken within a formal employment relationship (Berg, 2016; Ekbia and Nardi 2017; Wood et al., 2018; Howcroft and BergvallKåreborn, 2018; Moore and Newsome, 2018), the extent to which and how unpaid work then contributes to precariousness remains undertheorised to date. This sets us the challenge of moving beyond the traditional dichotomy between paid and unpaid work by developing a view of precariousness that encompasses different socio-economic modes and forms of work. Accordingly, we use the concept of 'dynamic interdependencies' (Gluksmann, 2005; Gershuny, 2000) in the sociology of work and define precariousness as resulting from subjective (e.g. exhaustion, mental and physical health) and objective (e.g. unsocial working hours, low (or no) pay) conditions that pose difficulties to people when planning for the future across the spectrum of their work and life. Thus, we identify the key analytical dimensions which shape these conditions within the continuum of paid and unpaid work activities and from which precariousness emerges. Although not all unpaid (or paid) work is precarious, unpaid (as well as paid) work may be precarious if undertaken under certain circumstances. Understanding these circumstances is therefore essential for developing a new and encompassing analytical and theoretical perspective for the study of precariousness.

This working paper is structured in four parts. In the first part, we will critically discuss the dichotomy between paid and unpaid work while investigating the micro-foundations of precariousness within recent transformations in labour markets. The second part will provide a review of existing literature in order to assess the growing emergence of unpaid work within the formal area of paid employment. In the third part, we will use this evidence to establish a heuristic framework that indicates the key dimensions underpinning precariousness within the continuum of paid and unpaid work. Finally, in the fourth and concluding part, we will present the implications of unpaid work for the workers' voice and trade unions. 


\section{Researching the micro-foundations of precariousness within the continuum of paid and unpaid work}

Macro-structural changes in the collective institutions of labour markets have strongly affected the way in which capital and labour have reorganised themselves, with important implications for the organisation of work, working conditions and employment relationships. This working paper investigates the micro-foundations of the deregulation process within the institution of the labour market. In the process, we ask how these macro-structural changes have come about in the first place and what have been the building blocks in the form of micro-social phenomena and processes underpinning their evolution. How employers use work serves the logic of value creation and capital accumulation under the growing centrality of 'rent-seeking' capitalism (Hoedemakers, 2017; Gill and Pratt, 2008). In this regard, we argue that the extent to which and how the undercutting of paid employment may involve, or even lead to, the creation of unpaid tasks becomes a highly relevant theoretical and empirical question.

Discussions in the literature on paid and unpaid work have often addressed these two concepts separately, leading to important implications as to 'what' (i.e. the work activity) and 'whom' (i.e. the worker) should be 'valued' within the work context. Accordingly, work has been (and is) valued as long as it yields a pecuniary (economic) return for an individual within the formal (waged) sphere of the employment relationship. Conversely, and in comparison to paid work, unpaid work lacks value because it is considered to be conducted within nonmarket-like exchange relations. ${ }^{1}$ The paid and unpaid work dichotomy reflects the understandings of classical sociology regarding the division of labour (Durkheim), which has underpinned the Fordist socio-economic 'male-dominated' order in post-industrial society. Accordingly, the paid/unpaid division reproduces the moral force and dignity associated with what is considered important in a 'cash' nexus or market-based economy, i.e. 'payment for doing something'. Thus, work that is monetised (paid) is valued, whereas work that is separated from the commodified dimension underpinning the economic logic of market exchanges and is unpaid is consequently not considered to be work, and therefore is not valued.

This view of unpaid work as being without value is reflected by the fact that unpaid work does not figure in any common economic measures of national growth (i.e. the Gross National Product or GDP). Daniels (1987) - and feminist

\footnotetext{
1. In consideration of the 'societal' (not 'individual') value of work (i.e. the extent to which work contributes to the functioning and prosperity of society), feminist studies have addressed the importance of work that falls outside the domain of paid (productive) work for the social construction (or reproduction in the private sphere) of daily life (Laslet and Brenner, 1989).
} 
studies (see, for example, Federici, 2012) - have eloquently illustrated the effects of this dichotomised view of work on women. In other words, under the traditional paid/unpaid dichotomy, women become 'displaced homemakers' whose major problem is 'the generally low worth placed on the work of women in the home' (Daniels, 1987: 406).

The separation between paid and unpaid work, where value is placed on remunerated work only, may explain the lack of any consideration of unpaid work within the formal sphere of paid employment in the study of precariousness to date. In other words, because unpaid work has generally been conceived as having no value (i.e. informal work in the private sphere), it has not been associated with precarious work, which conversely remains strongly anchored to the paid (formal) element of employment. However, in different ways and forms, contemporary sociological theories argue powerfully in support of overcoming the paid/unpaid work distinction. For example, Beck (2000) has stated that sociology should challenge the 'value imperialism' of paid over unpaid work, as the former is always seen as 'real' work, whereas unpaid labour is not. Likewise, Bourdieu's (1988) claim that job insecurity is 'everywhere now' emphasises the broad character of insecurity. Furthermore, according to Hacker (2006), the shifting of risks within an era of economic uncertainty incurs not only drops or interruptions in income deriving from paid work but, more frequently, significant unexpected expenses for individuals in connection with their health, education and any form of investment in their domestic lives. More recently, Kalleberg and Vallas (2018) have suggested opening up the 'black box' of precariousness by investigating the rich plethora of different activities and/or events which may foster uncertainty and social risk for individuals in society. Moreover, Hyman (2018) argues for investigating the underlying reasons why people undertake labour that falls within the sphere of re-commodified work and is both economically and socially unprotected.

Hence, considering work merely as a 'discrete activity carried out in exchange for remuneration and dependency' (Parry, 2005: 10) is limiting. Furthermore, changes that have taken place in the context of both paid and unpaid work over the past few decades strongly support this view. These changes are relevant to the study of precariousness for the following reasons: firstly, paid work is increasingly disconnected from any form of permanent income that used to guarantee economic security by generating dependency through welfare (Bosch, 2004). Nowadays, contracts covering paid work are increasingly diverse, and they often place workers on 'on-call' employment contracts in which pay levels and work schedules vary sharply from worker to worker (Rubery and Grimshaw, 2016). Secondly, unpaid work has gradually shifted away from its social reproductive and voluntary character. For example, voluntary traineeships have increasingly become contractual devices for first jobs for which young people (often graduates) are recruited under casual employment conditions (Lee, 2015). In addition, unpaid work is increasingly used to replace paid activity within social (for-profit and not-for-profit) service providers. This is, for example, the case for care services (Baines et al., 2017) because of marketisation, outsourcing and privatisation processes that make employment subject to the sector's overall principles of public management and the work-first welfare state (Greer et al., 2017). 
Although moving towards an all-encompassing definition of work may be inevitable, how to do this in practice is still not clear. Social scientists are confronted with the theoretical and empirical challenge, first and foremost, to create the tools that will enable exploration of the various forms that work takes. Moreover, existing secondary datasets - particularly cross-national surveys which are often used to study precariousness (Labour Force Survey (LFS) and the European Working Conditions Survey (EWCS)) do not capture the unpaid activities underpinning labour market restructuring. For example, current indicators of precariousness include only those features that are related to paid work (Van Aerden et al., 2014; Pyöriä and Ojala, 2016; Olsthoom, 2014; Ferreira, 2016).

This working paper is a first attempt at establishing a heuristic analytical framework for the study of precariousness at the continuum between paid and unpaid work. This approach complements existing knowledge, assessing the extent to which and how current structural transformations have contributed to shaping individuals' (precarious) work and life experiences by first departing from these experiences. To that end, the following sections will present three case studies, corresponding to three areas of work (i.e. care work, creative work and digital work), in order to illustrate the growing relevance that unpaid work has acquired and the diversified forms (or modes) that it can take within each area. We are aware that these forms may not be exhaustive in terms of the actual situation surrounding individuals' experience of unpaid work, and it is for this reason that we set about establishing an analytical framework. This framework can be used as an inductive heuristic tool in future research in order to explore the uncharted territory of unpaid work within paid employment.

The reasons for selecting these three areas of work are that: (1) they span both traditional (e.g. care) and emergent forms of work (i.e. digital and creative); (2) they have all been involved in recent waves of restructuring as the result of new technology and new organisational work practices. These work areas intersect with the 'contested' values of social and regulatory (institutional) regimes for social protection, production structures and gender roles that are expressed most strongly in care work (e.g. when compared to the work of software developers) but are also present in the other two areas of work. Evidence gathered from each case study is based on secondary literature. We will draw on the narrative of the case studies in order to identify a number of key dimensions which we will use to develop the heuristic analytical framework for the study of precariousness within the continuum of paid and unpaid work. 


\section{Three case studies of unpaid work}

\section{Care work}

The care sector is one of the main sources of new jobs in Europe (European Commission, 2013). In response to the marketisation of employment services, 'hybrid' forms of paid and unpaid work have emerged in the care sector. In particular, for the purpose of raising budget constraints and facilitating organisational restructuring driven by New Public Management (NPM), unpaid work has been used to replace paid activity within private (for-profit and/or not-for-profit) care providers (Schwarts, 2013). Practices of unpaid work involve family care-givers who often benefit from cash-for-care schemes, as well as those accepting available jobs for whom the receipt of benefits is contingent on their actively seeking work.

In Europe, a number of countries have gradually moved towards the deployment of hybrid forms of paid and unpaid work in the care sector, albeit at different speeds and in different ways. For example, Sweden has moved from public care services to the privatisation and re-familialisation of the care supply (Stranz and Szebehely, 2017; Meagher and Szebehely, 2013). The United Kingdom has further lowered the labour costs of the welfare supply through the use of both (low-)paid (e.g. zero-hour contracts) and unpaid (e.g. communitybased services) work, supplied by beneficiaries of unemployment benefits (Daguerra and Etherington, 2014). The increase in care provision at home in France, Germany and Belgium is driven by a job creation strategy aimed at lowering labour costs in the formal (paid) labour market by funding care through vouchers and cash-for-care schemes on the one hand, and the use of unpaid (domestic) work subsidised by a minimum income scheme on the other (Kross and Gottschall, 2012). Likewise, in Italy, there is a high incidence of often undeclared low-paid and informal (unpaid) work (Simonazzi, 2009). As a consequence of reforms aimed at broadening private provisions within Eastern Europe, countries such as Poland have also undertaken the ongoing retrenchment of the public welfare supply and are seeing an increase in family care whereby unpaid work is being undertaken mostly by women (Sirovátka and Greve, 2015).

Two considerations are worth mentioning here. Firstly, under the request to 'do more with less' (Davies, 2011), employers in formal employment contexts in the care sector expect workers to take on unpaid work as an expression of their 'love for others' (Szebehely and Trydegård, 2012). Unpaid work can involve both the tight control of working time (Rubery et al., 2015), including time 
spent travelling between different client locations (McCann, 2016; Macdonald and Charlesworth, 2016), and the aforementioned re-familialisation of work by domestic work (Simonazzi, 2009). Secondly, with significant differences across a great many countries in Europe, the care sector boasts high rates of part-time work and temporary contracts (European Commission, 2013). This is hardly surprising considering that women are segregated into care-related tasks. What is also hardly surprising is that workers on temporary contracts and employed under casual work arrangements - since the employer often does not guarantee a minimum number of working hours or salary - have a tendency to volunteer more, or generally be more open to undertaking unpaid working hours, than all the other categories of workers, because they are frequently asked for volunteer references when seeking employment (Lewchuk et al., 2015).

\section{Creative work}

Creative workers are highly skilled and have a high personal investment in both formal education and 'learning by doing' activities. However, creative workers are also highly heterogeneous. A first broad distinction can be drawn between those employed by companies - i.e. dependent workers - who often benefit from stable work contracts, good wages and fair working conditions, and those contracting out their skills to small and flexible organisations and/or individual clients - the 'self-employed' - who suffer the most from a low income, high uncertainty and poor working conditions (Bellini et al., 2018).

For creative workers who are self-employed, work has become increasingly competitive owing to the growing dominance of the free-market rationale which progressively reduces the rates of pay at which services and/or products are offered by those who take responsibility for their own creativity (Bologna and Fumagalli, 1997; Antcliff et al., 2007; Townley and Beech, 2010; Hoedemakers, 2017). This is true, for example, for freelancers in the media industry (e.g. journalists) who are often isolated and must compete against the hordes of unpaid informers churned out by the social media (ETUI, 2017).

The number of self-employed freelancers has grown by $24 \%$ during the period 2008 to 2015 in Europe, with the highest growth being seen in the United Kingdom, the Netherlands and France. This growth has helped to foster job creation, although it is difficult to establish a causal relationship between the growth of self-employment and creative jobs. Sweden, for instance, retains the lowest percentage of self-employment in Europe despite having the largest creative economy employment share in Europe, with $11.92 \%$ of employment in the sector (Nathan et al., 2015).

Unpaid work within the creative industries can serve as a vehicle to securing paid work (see also the following section on digital work) or it can take the form of traineeships as an entry route into employment (Lee, 2015). Traineeships in the creative industries are considered to help people acquire 'social capital', enabling them to get to know key people and become part of professional networks, both of which are important for pursuing a career within the industry 
(Frenette, 2013). However, several studies have shown that most trainees fail to find employment in the same industry (Siebert et al., 2013), and that, as a result, the career path of those who work in the creative industries is, for the most part, uncertain and complex (Swartz, 2018). Moreover, income from paid traineeships may be lower than the minimum wage of the country in which it takes place (OECD, 2016), and for some professions (e.g. architecture), the term 'intern' is commonly used as code for someone who works for 'free' (Keegan, 2010).

\section{Digital work}

In an era when people's ability to establish their own website, blog or YouTube account seems to promise the possibility of their making a living off of doing what they love - a phenomenon that Duffy (2017) has recently dubbed 'aspirational work' - there may be a tendency for a good number of workers to invest an increasing proportion of their time (unpaid working time) in a bid to promote their online presence (Cherry, 2011; Graham et al., 2017).

Studies have shown that programmers frequently participate in corporate-led 'hackathons', mobilising their skills without compensation and without any property rights to the products they themselves create (Zukin and Papadonatakis, 2018). Moreover, participants in platform-based firms must spend a great deal of time establishing an online presence, and frequently engage in lengthy efforts to compete for projects, with no certainty of reward (Aloisi et al., 2017; Ekbia and Nardi, 2017).

Online platforms (e.g. Upwork, Freelancer, Amazon Mechanical Turk) enable individuals to gain virtual access to other individuals at global level in order to resolve specific problems and provide services in person and/or in situ (e.g. Deliveroo, Care.com, Uber) (see Eurofound, 2015). Online workers can be both high- and low-skilled (Wood et al., 2018) depending on the nature of the tasks (macro or micro) they perform (Gerber and Krzywdzinski, 2017). Several studies have highlighted the vulnerability of digital work by shedding light on the power asymmetries enshrined in digital platforms between the platforms owners and the users (European Parliament, 2017; Lehdonvirta, 2016). These asymmetries are reflected in the nature of the work and the modes through which it is enacted.

Zysman and Newman (2006) use the term 'putting-out economy' to describe digital work. In the current manifestation of 'putting out', platform workers lack control over compensation for the work they do. Although it could be argued that workers are able to retain some autonomy over their place of work, which in turn can be helpful to individual workers in overcoming the barriers to labour market participation (Pesole et al., 2018), more recent research on digital work has shown that this autonomy cannot reduce workers' exposure to unpaid activities, particularly when unpaid work becomes a condition for securing paid work (Wood et al., 2018). This has an unprecedented social impact on workers. On the one hand, workers need to make themselves available as and 
when required by the market and be prepared to do unpaid work, including, for example, searching for tasks, taking qualification tests and researching requesters, doing preparatory work (Berg, 2016) and working unsocial hours in order to secure paid work (Wood et al., 2018). On the other hand, and somewhat controversially, workers are likely to become economically more insecure, especially when the performance of the tasks they undertake represents a not insignificant part of their income. In a survey of American and Indian online workers, Brawley and Pury (2016), for example, found that digital work was the main source of income for $39 \%$ of the 225 American workers surveyed, and for $41 \%$ (54 out of 132) of the Indian workers. Similar results were found by Berg (2016) when comparing the situation of workers in the USA and Europe, and by Aleksynska et al. (2018) when surveying digital workers in Ukraine. 


\section{A heuristic framework for precariousness within the continuum of paid and unpaid work}

Evidence gathered from these areas of work demonstrates that, in most cases, unpaid activities form part of paid work. This is more likely to occur when, for example, unpaid work becomes a precondition for securing paid work (e.g. within digital and creative industries). This observation has relevant implications for theory-building around precarious work, since it demonstrates that work can no longer be characterised as either paid or unpaid, and that assessing precariousness by looking only at paid work runs the risk of overlooking an important series of tasks that individuals undertake in order to complete their work. By contrast, it highlights the borderless and seamless fluidity of work, whose activities straddle the boundaries of the paid and unpaid dichotomy.

In this section, we draw on this observation in order to construct a heuristic analytical framework for advancing the study of precariousness which encompasses different work activities (both paid and unpaid). This implies that precariousness should be considered as unfolding along the continuum of work, ranging from wholly non-monetised (unpaid) to wholly monetised (paid) activities. We hold that this is crucial for the advancement of theory within the field of work and precariousness, because it (1) enables a more nuanced view of the underlying activities and associated social relations; (2) helps to link the various paid and unpaid work activities (and their diverse forms) to precariousness by assessing their social implications on individuals' life and work experiences.

Evidence from the care, creative and digital industries illustrates that unpaid work may take different forms (e.g. preparatory work, long and unsocial working hours, work during unpaid traineeships, domestic work, work supplied by beneficiaries of social benefits, etc.), all of which contribute to shaping this unpredictability. This means that precariousness does not occur in a vacuum but is contingent upon the contextual (institutional and social) conditions (i.e. the social environment) in which individuals are embedded, and which in turn contribute to influencing the extent to which (and how) they undertake unpaid work. Social norms and values (known as culture) are also part of the social environment, since they contribute to structuring the social regimes (e.g. gender) within which people may undertake some activities rather than others (see also the following section).

We hold that, under these conditions - into which further research is required individuals are influenced by their capacity to: (1) follow their personal aspirations, and hence have the capacity (or not) to act voluntarily; (2) exercise (or not) 
control over their work and life; and (3) earn (or not) a permanent income, which can protect them against the risk of having to undertake unpaid work as a pathway to economic security, for example. Thus, we use these three key dimensions (i.e. (in)voluntary work, control over work, and economic dependency) to operationalise precariousness as the social and economic unpredictability that individuals face with regard to their own future. Accordingly, we expect these three dimensions to affect the extent to which (and how) individuals take up unpaid work under specific contextual (e.g. institutional) and social (e.g. gender, age, household composition) settings and circumstances (see Figure 1).

\section{Figure 1 Heuristic framework}

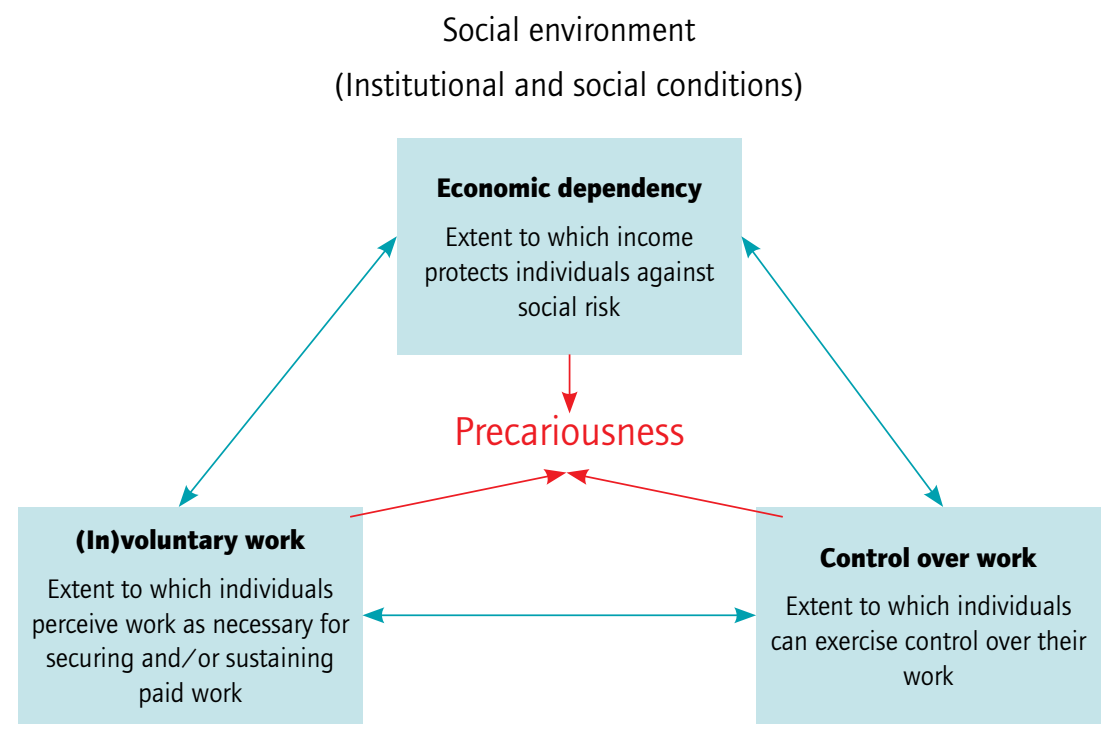

Source: Own elaboration

The reasons for selecting these three key dimensions are specified below by linking them to existing theories and studies in the field of work and employment relations:

1. (In)voluntary work reflects individuals' motives, preferences and needs which are considered important when assessing the degree to which a type of work presents a problem or an opportunity for the worker (Kalleberg, 2018). However, individuals' preferences and aspirations are influenced by the perceptions people have within a given contextual situation. As a result, people who voluntarily opt for a specific set of activities (or job) may be less likely to experience unpaid work unless they perceive it as a necessary means of securing or sustaining paid work (e.g. ESOPE, 2002). By the same token, workers may be persuaded to follow their aspirations by performing unpaid tasks if this increases the likelihood of their securing 
a paid job. For instance, studies have shown that individuals undertake unpaid work (tasks) on digital platforms not because they have willingly chosen to do so but because unpaid work is a means of gaining access to paid work (e.g. Wood et al., 2018). Similarly, individuals' predisposition to 'care for others' encourages them to undertake unpaid work in care, consisting in either domestic (unpaid) or dependent (both formal and informal) work performed by beneficiaries of cash-for-care schemes and/ or subsidised by minimum income schemes (Simonazzi, 2009; Kross and Gottschall, 2012). For example, in creative industries, artists (e.g. musicians or dancers) are prepared to undertake unpaid work as a means of improving their career prospects in a world where social networks and personal aspirations influence career choices in specific fields (Greer et al., 2017).

2. Control over work refers to the individual's influence over work content and working conditions (including working hours) as dimensions of job quality (Gallie, 2009). Control over work is usually seen as reducing exposure to unpaid work. However, it may also increase it. For example, evidence gathered from creative and digital workplaces illustrates that the self-employed - whose employment status should, in principle, allow them control over their work schedule - undertake unpaid work as a means of gaining more clients (see Wood et al., 2018 on digital platforms; and Van Assche et al., 2018 on creative industries). This can have an impact on individuals' ability to manage the tensions between work and family life (Lewchuk, 2017) which are contingent on skills (Gerber and Krzywdzinski, 2017) and gender roles (Schor et al., 2015).

3. Economic dependency implies that security depends on the extent to which income protects individuals against social risk (Ferreira, 2005), thereby reducing individuals' propensity to undertake unpaid work. Evidence gathered on digital platforms and creative work seems to confirm this assumption, since it shows that unpaid work is relatively more common in situations of self-employment than in the case of dependent contracts (Berg, 2016). However, we should acknowledge that some exceptions may exist through bogus self-employment. Research into care work also seems to confirm that the propensity to undertake unpaid work is likely to increase where income dependency is lowest, since workers in care who undertake unpaid work are mostly women on fixed-term and part-time employment contracts. However, this hypothesis does need to be tested empirically.

Expanding the notion of precarious work to both its paid and unpaid dimensions has a number of relevant analytical implications for the way in which we assess work outcomes as a manifestation of the key dimensions of precariousness (i.e. (in)voluntary work, control over work and economic dependency) identified within the heuristic framework (Figure 1, p. 15). For example, with regard to the key dimension of economic dependency, considered to protect people from social risks, the extent to which unpaid work is detrimental to an individual depends on the amount and scope of the social protections that characterise the different typologies of employment (i.e. permanent, temporary and self- 
employed) as well as the different types of job people undertake within different national regulatory contexts (i.e. the social environment). These typologies strongly intersect with the social categories of gender, age and ethnicity so that segmentation between good and bad jobs in the labour markets is often indicative of more in-depth social fissures among different social groups within society (Grimshaw et al., 2017). For example, Rubery et al. (2016) have argued that inclusive employment systems that increase job security are not sufficient and that inclusive labour markets, supported by employment regulations that promote inclusive employment practices, are equally important. Furthermore, unpaid work in relation to the key dimension of control and discretion at work can potentially be more of an issue for people who are continuously seeking a job that provides an income because of the proliferation of volatile and short(or zero-) hour contracts. Owing to the different regulatory arrangements for flexibility laid down at national level, the extent to which unpaid work is detrimental is likely to vary depending on the national institutional and regulatory framework for social protection, with the most disadvantaged being those living in countries with less inclusive systems for social protection, such as the United Kingdom. However, it can also be argued that income as a means of guaranteeing people economic security, and therefore independence - which is often contingent upon skill level - is also a relevant feature which can influence the extent to which unpaid work in relation to the key dimension of control can be detrimental. Finally, and in direct connection with this consideration, unpaid work in relation to the dimension of voluntary/involuntary work is likely to be more of an issue when the need to catch up with work, as a condition for an individual's receiving income, undermines the voluntary nature of the job/ task. This in turn reflects the insignificant amount of control and discretion exercised by the individual over his/her work.

Generally speaking, (in)voluntary work, control over work and economic dependency as the three key dimensions of precariousness within the continuum of paid and unpaid work are not separate but interlinked features embedded within specific social contexts. Hence, we can identify the causal variables ranging from the level of the interaction between these dimensions and the social (institutional and regulatory) environment where the conditions affecting specific outcomes are likely to occur. This is in line with recent work by Kalleberg (2018) which illustrates the relevance of the institutional and social context in shaping precarious work. We expand on this view by extending previous analyses to include unpaid work. In particular, we infer that interpretations and experiences of unpaid work will indicate a variety of ways in which unpaid work can evolve into paid work. In other words, the variety of different forms of unpaid work is revealed through the subjective expectations that people have brought to bear, depending on their position within the social environment. In so doing, the novelty of the theoretical ideas about precariousness within the paid/unpaid continuum incorporate insights from Bourdieu's (1984) concept of the 'habitus' when referring to the possibilities open to individuals as capital (economic, cultural, social) becomes embodied in the form of varying 'dispositions' (i.e. the 'habitus') and 'outlooks' (Atkinson, 2010). 


\title{
Workers without work: implications for the workers' voice and trade unions
}

\begin{abstract}
A large body of research has discussed the conditions under which conventional trade union channels for the workers' voice can successfully moderate or reduce precariousness (Doellgast, Lillie and Pulignano, 2018). Nevertheless, the understanding of precarious labour markets promoted by these studies is firmly anchored in work within the formal sphere of paid employment relationships. As this working paper illustrates, however, there are many instances where work tasks emerge in the form of unpaid work. Our heuristic framework (see Figure 1, p. 15) indicates three dimensions around which unpaid work - albeit to varying degrees and in different forms - may occur. This comes about because these tasks are often associated - and largely confused - with tasks that are not formally considered to be part of the job (e.g. preparatory tasks are considered as voluntary), and therefore they are said to fall outside the legal employment structure (i.e. employment status).
\end{abstract}

The performance of tasks as part of a job that are not considered paid work by the employer poses new challenges for trade unions. This is because workers engaged in performing unpaid work see their efforts as not being valued, neither materially nor symbolically. Thus, they may be less likely or willing to organise themselves or to use their voice and/or the legal system to appeal for public support in order to challenge their working conditions. Moreover, even though workers who undertake unpaid work may be willing to mobilise themselves, the invisibility and unvalued nature of their work - and, in many cases, of the workers themselves - may make it difficult for them to gain political traction, and so they may be pushed towards supporting far-right populism. In a recent article on trade union organising in Europe and the United States, Matie Tapia and Lowell Turner (2018) put forward a similar argument in claiming that the failure of various national labour movements and (social)-democratic political parties to advocate in a comprehensive and effective way for the interests of modern diverse working and middle classes is one of the causes of the rise of populism. As a result, the deepening solidarity that comes in response to the major issues facing trade unions today is unlikely to be without its challenges.

Can trade unions reverse the current state of play? Research shows that innovative organising strategies for vulnerable social groups are more likely to emerge when trade unions combine new approaches with existing structures (Simms et al., 2018). In analysing the situation of freelance musicians in Slovenia, France and the United Kingdom, for example, Greer et al. (2018) demonstrate how engaging in novel and effective strategies that make it possible to 'bring the market under control' was crucial for the trade unions in these countries in 
organising and representing freelance musicians. Constitutive elements of these new approaches have involved, for example, unions increasing and enforcing overall minimum standards as well as providing services to help freelancers navigate the market, including access to legal advice and courses on negotiation and marketing. This implies that unions need to be able to move 'a scale of activity beyond the enterprise' (Heery, 2009: 434). Specifically, evidence in the Anglo-Saxon context shows that trade unions have made themselves more attractive through their low membership fees by moving their efforts beyond thinking in terms of workers' needs within traditional workplaces, such as membership fees for permanent industrial workers (Heery et al., 2004; King, 2014). Particularly relevant here is the 'freelancer unions' which have influenced remuneration and other terms and conditions through draft contracts and fee sheets which specify recommended pay rates for different work tasks (Heery et al., 2004; Umeny, 2016).

This working paper shows that social groups that are most at risk of undertaking unpaid work often experience low (or unsustainable) pay conditions. They are often seeking more work 'to make their day's pay' (e.g. in creative and digital work areas), and therefore often cannot afford to pay the normal membership fee. Trade unions' approach of reducing membership fees can benefit these workers. Other cases involve the establishment of alternative institutions of worker representation, such as coalitions or communities of interests (Frege et al., 2004), occupational (and/or virtual) networks and forums (Saundry et al., 2006). In general, these examples illustrate that a number of trade unions have successfully reframed their role by developing a 'credible' collective account or rationale for organising and representing workers beyond the traditional (paid) dependent employment relationship.

Extensive employment and industrial relations studies have been conducted on the causes of the decline in trade union membership and the threat it poses to union legitimacy. A number of these studies include among the factors affecting the decline in trade union membership the following conditions: (1) economic, i.e. unemployment or contractual employment features (e.g. temporary and part-time versus permanent contracts), and changes in the political context, e.g. involving national governments and political alliances; (2) structural changes, i.e. the transition from manufacturing to service-sector jobs, globalisation and Europeanisation; and (3) cultural, i.e. anti-union behaviour by management. This working paper brings an additional factor to the table: the trend towards fragmentation and unbundling of tasks within increasingly competitive labour markets. This factor inhibits the unions' capacity to organise in deregulated labour markets. In particular, we hold that the dispersion of jobs under current business restructuring has increased the complexity of union action and legitimacy by threatening the configuration of both what is traditionally conceived as 'work' (i.e. the activities which are tied to a job and its rewards, and which are covered by a formal employment contract) and the 'place' where it is performed (i.e. the workplace). According to existing theory, this is because an employment contract defines the activities and conditions required at the workplace by the employer, since it is from these activities and conditions that management is enabled to reap a profit (Edwards, 2003). Accordingly, it is these 
activities and conditions, which lie at the core of the employment relationship, that make work 'valued'.

Nowadays, trade unions are confronted with an increasingly long series of 'devalued' work activities that have emerged from recent labour market changes. In referring to 'devalued' activities, we focus on a more fundamental principle of 'value' in labour, i.e. whether the task is recognised as being worthy of inclusion in the category of work and of being regulated as such. Some types of work activities that are devalued by the market economy are treated as such simply because they are not valued among the buying and selling aspects of an employment transaction. Current studies into the institution of employment argue that the weakening of industrial relations institutions, including the decline of labour power, have concurred to increase deregulation by eliminating constraints upon employers' discretion (Baccaro and Howell, 2017). We hold that the devaluation of some work activities also concurs to enhance employers' discretion by reducing the limitations of what is conceived as ('the meaning of') work. Sociology and cultural studies theory (e.g. Hall et al., 2013) help our understanding of the dynamics and mechanisms shaping this occurrence. Management discourses on 'accountability' propagate the idea of unpaid work as 'devalued' work. Evidence drawn from creative and digital work and presented here illustrates that highand low-skilled workers are associated with a wide range of uncoordinated and dispersed tasks or activities (e.g. driving, home repair, grocery shopping, translation, software programming), for which the worker is considered to be socially 'accountable' and 'responsible'. This is similar to care work where the desire to 'care for others' corresponds to legitimate unpaid work within paid care employment. Thus, aside from institutional structures, cultural and ideological aspects also explain how unpaid work comes about and may promote precarity as a condition of work and life (Leroy, 2015). In his recent book on precarious work, Kalleberg (2018) makes a similar argument when stating that cultural variations in social norms and values help a country's institutions and practices in delivering precarity. Accordingly, we may expect that the level of remuneration and reward for labour within the work process depends more on the employer's definition of 'value' than on the worker's effective output.

Can trade unions influence management discourses through which unpaid work is promoted as 'accountable' and therefore 'taken for granted' and unworthy of being valued? Hyman and Gumbrell-McCormick (2010) urge trade unions to rethink democracy. This implies unions changing their traditional culture in order to be able to reconcile the contraposition of different dimensions of union democracy and various union strategies towards the representation of workers who face the consequences of 'the race to the bottom' (Haake, 2017). In a recent comparative research study on trade unions, democracy and precarious work conducted by Marino, Bernaciak, Mrozowicki and Pulignano published in 'Economic and Industrial Democracy', the authors claim that the notion of democracy can be useful when discussing how trade unions can expand while reinforcing representation of the post-industrial and often 'invisible' workforce. In particular, organisational democracy can offer legitimacy 'from below' to 
representative approaches, while also providing 'recognition from above' for organising approaches and the integration of workers' concerns into trade unions' agendas. The involvement of partial constituencies in the formulation of general union demands can deliver efficacy (economic goods) and democracy (participation) to diverse groups of workers who are struggling on low or no pay. It can also support the cultivation of transversal solidarities within the working class by developing a more inclusive internal union culture. 


\section{Conclusions}

The main focus of this working paper is the emergence of unpaid work as the micro-foundation of labour market deregulation. On the one hand, unpaid work emerges from the fragmentation of jobs and the isolation of the workforce. On the other hand, it reinforces deregulation by misrepresenting specific tasks as work that are not considered to be part of a job and so are not valued. This observation is supported by the analysis of the case studies presented in this paper, illustrating that unpaid work coexists with paid work for a significant proportion of the workforce, within both traditional and new work arrangements. Unpaid work is brought into the conventional domain of paid employment as tasks an individual performs but which are not considered as complementing - or being related to - his/her main 'work' activity or job. We have argued that the absence of coordination across different tasks a worker undertakes - the traditional notion of what constitutes a 'job' - facilitates the proliferation of unpaid work as the manifestation of uncertainty and precariousness within current deregulated labour markets. As such, unpaid work often constitutes work that people do in order to secure paid work or work that people perform under the assumption that it is not part of the 'normal' job and is therefore voluntary. In so doing, unpaid work engages the working population in a 'race to the bottom', with deteriorating working conditions and labour standards for workers as a collective. Interestingly enough, unpaid work nowadays has a great deal to do with the socio-economic features of capital accumulation that were typical of the pre-industrialisation period and were characterised by the absence of collective structures for 'risk sharing'.

Employers' freedom to create fragmented and precarious work unfolds within the paid and unpaid (work) continuum. This freedom consists of structural and cultural factors (e.g. regulatory arrangements and personal aspirations) that employers use in order to elicit and legitimise unpaid work. Therefore, acknowledging the diversity of factors and the variety of channels driving the expansion of precarious work within the paid and unpaid work continuum can help trade unions, national governments and communities in general to combat the practical and cognitive mechanisms through which precariousness unfolds. We believe it can also support unions' broad understanding of precariousness as a complex socially constructed phenomenon that blurs different conceptions and forms of work in current social contexts. An understanding of the various forms and conceptions of 'work' and the 'worker' is an essential precondition for unions' developing novel discourses of representation and social democracy in today's society. However, an understanding alone of the nature of work may fall short of what is needed to tackle precariousness. Trade unions must also 
undertake a number of significant actions in this respect, entering the 'spaces' of work and life and making themselves attractive by providing people with the resources they lack in order to gain access to 'good quality' jobs as a means of improving their social conditions and lives. Conversely, it can also be argued that, if the State, legal systems and trade unions fail to acknowledge unpaid work as being worthy of respect and dignity, and therefore deserving of being valued in the first instance, there will be far less scope for this work to be addressed in policy and/or law. 


\section{References}

Aloisi A. (2016) II lavoro "a chiamata" e le piattaforme online della collaborative economy: nozioni e tipi legali in cerca di tutele, Labour \& Law Issues, 2 (2), 16-56.

Antcliff V., Saundry R. and Stuart M. (2007) Networks and social capital in the UK television industry: the weakness of weak ties, Human Relations, 60 (2), 371-393.

Baccaro L. and Howell C. (2017) Trajectories of neoliberal transformations, Cambridge, Cambridge University Press.

Baines D., Cunningham I. and Shields J. (2017) Filling the gaps: unpaid (and precarious) work in the nonprofit social services, Critical Social Policy, 37 (4), 625-645.

Beck U. (2000) The brave new world of work, Cambridge, Polity Press.

Bellini A., Dorigatti L. and Burroni L. (2018) Industrial relations and creative workers. Country report: Italy. https://www.researchgate.net/publication/325146772_Industrial_ relations_and_creative_workers_Country_report_Italy

Berg J. (2016) Income security in the on-demand economy: findings and policy lessons from a survey of crowdworkers, Geneva, ILO.

Bologna S. and Fumagalli A. (eds.) (1997) Il lavoro autonomo di seconda generazione: scenari del postfordismo in Italia, Milano, Feltrinelli.

Bosch G. (2004) Towards a new standard employment relationship in Western Europe, British Journal of Industrial Relations, 42 (4), 617-636.

Bourdieu P. (1984) Distinction: a social critique of the judgement of taste, London, Routledge.

Bourdieu P. (1998) Acts of resistance: against the tyranny of the market, Cambridge, Polity Press.

Brawley A.M. and Pury C.L.S. (2016) Work experiences on MTurk: job satisfaction, turnover, and information sharing, Computers in Human Behavior, 54, 531-546.

Cherry M. (2011) A taxonomy of virtual work, Georgia Law Review, 45 (4), 951-1014.

Conen W. and de Beer P. (2017) The value of work in a changing labour market: a review and research agenda. http://www.arbeidsconferentie.nl/uploads/submission/ document_1/160/Conen_Value_of_Work_Literature_review.pdf

Crain M., Poster W. and Cherry M. (eds.) (2016) Invisible labor: hidden work in the contemporary world, Oakland, University of California Press.

Daguerre A. and Etherington D. (2014) Workfare in 21 st century Britain: the erosion of rights to social assistance, Working Paper 2014.11, London, Economic and Social Research Council. http://workfare.org.uk/images/uploads/docs/Workfare_in_21st_century_Britain-Final.pdf

Daniels A.K. (1987) Invisible work, Social Problems, 34 (5), 403-415.

Davies J.S. (2011) Challenging governance theory: from networks to hegemony, Bristol, Policy Press.

De Groen W.P. and Maselli I. (2016) The impact of the collaborative economy on the labour market, CEPS Special Report 138, Brussels, Centre for European Policy Studies. https:// www.ceps.eu/system/files/SR138CollaborativeEconomy_0.pdf 
Dekker F. (2010) Self-employed without employees: managing risks in modern capitalism, Politics \& Policy, 38 (4), 765-788.

Doellgast V., Lillie N. and Pulignano V. (eds.) (2018) Reconstructing solidarity: labour unions, precarious work, and the politics of institutional change in Europe, Oxford, Oxford University Press.

Dörre K. (2015) Tests for the underclass: the social effects of activating labour market policy in Germany, in della Porta D., Hänninen S., Siisiäinen M. and Silvasti T. (eds.) The new social division: making and unmaking precariousness, Basingstoke, Palgrave Macmillan, 83-100.

Duffy B.E. (2017) (Not) getting paid to do what you love: gender, social media, and aspirational work, New Heaven, Yale University Press.

Edwards P.K. (2003) The employment relationship and the field of industrial relations, in Edwards P.K. (ed.) Industrial relations: theory and practice, 2nd ed., Oxford, Blackwell.

Ekbia H.R. and Nardi B.A. (2017) Heteromation, and other stories of computing and capitalism, Cambridge, MIT Press.

Eurofound (2015) New forms of employment, Luxembourg, Publications Office of the European Union.

European Parliament (2016) Precarious employment in Europe: patterns, trends and policy strategies, IP/A/EMPL/2014-14.

European Parliament (2017) The social protection of workers in the platform economy, IP/A EMPL/2016-11.

Ferreira M. (2016) Informal versus precarious work in Colombia: concept and operationalization, Progress in Development Studies, 16 (2), 140-158.

Frenette A. (2013) Making the intern economy: role and career challenges of the music industry intern, Work and Occupations, 40 (4), 364-397.

Gallie D., Felstead A., Green F. and Inanc H. (2017) The hidden face of job insecurity, Work, Employment and Society, 31 (1), 36-53.

Gerber C. and Krzywdzinski M. (2017) Schöne neue Arbeitswelt? Durch crowdworking werden aufgaben global verteilt, WZB Mitteilungen, 155, 6-9.

Gershuny J.I. (2000) Changing times: work and leisure in postindustrial society, New York, Oxford University Press.

Gill R. and Pratt A. (2008) In the social factory? Immaterial labour, precariousness and cultural work, Theory, Culture and Society, 25 (7-8), 1-30.

Glucksmann M.A. (2005) Shifting boundaries and interconnections: extending the 'total social organisation of labour', The Sociological Review, 53 (2), 19-36.

Graham M., Hjort I. and Lehdonvirta V. (2017) Digital labour and development: impacts of global digital labour platforms and the gig economy on workers' livelihoods, Transfer, 23 (2), 135-162.

Greer I., Breidahl K.N., Knuth M. and Flemming L. (2017) The marketization of employment services and the dilemmas of Europe's work-first welfare states, Oxford, Oxford University Press.

Griffith E. (2018) Sociologists examine hackathons and see exploitation, Wired, 20 March 2018. https://www.wired.com/story/sociologists-examine-hackathons-and-seeexploitation/

Hacker J.S. (2006) The great risk shift: the assault on American job, families, health care and retirement and how you can fight back, New York, Oxford University Press.

Hall S., Evans J. and Nixon S. (eds.) (2013) Representation: cultural representations and signifying practices, London, Sage. 
Heery E. (2009) Trade unions and contingent labour, Cambridge Journal of Regions, Economy and Society, 2 (3), 429-442.

Heery E., Conley H., Delbridge R. and Stewart P. (2004) Beyond the enterprise: trade union representation of freelance workers in the UK, Human Resource Management Journal, 14 (2), 20-35.

Hyman R. (2018) Is forced labour the new 'normal', Key note presented at the Industrial Relations in Europe Conference (IREC) 2018, Leuven, Belgium, 10-12 September 2018.

Hyman R. and Gumbrell-McCormick R. (2010) Trade unions, politics and parties: is a new configuration possible?, Transfer, 16 (3), 315-331.

Hochschild A.R. (1983) The managed heart: commercialisation of human feelings, California, University of California Press.

Hoedemakers L. (2017) The changing nature of employment: how technological progress and robotics shape the future of work, Master Thesis, Lund University. http://lup.lub.lu.se/ student-papers/record/8916714

Howcroft D. and Bergvall-Kåreborn B. (2018) A typology of crowdwork platforms, Work, Employment and Society. https://journals.sagepub.com/ doi/10.1177/0950017018760136

Illich I. (1981) Shadow work, Boston, Marion Boyars.

Kalleberg A. (2009) Precarious work, insecure workers: employment relations in transition, American Sociological Review, 74 (1), 1-22.

Kalleberg A. (2018) Precarious lives: job insecurity and well-being in rich democracies, London, Polity Press.

Kalleberg A.L. and Vallas S.P. (eds.) (2017) Precarious Work, Bingley, Emerald Publishing. Keegan E. (2010) The unpaid staff, The Journal of the American Institute of Architects, 13 September 2010. https://www.architectmagazine.com/practice/best-practices/theunpaid-staff_o

King M.W. (2014) Protecting and representing workers in the new gig economy: the case of the freelancers union, in Milkman R. and Ott E. (eds.) New labor in New York: precarious workers and the future of the labor movement, Ithaca, Cornell University Press, 150-170.

Kroos D. and Gottschall K. (2012) Dualization and gender in social services: the role of the state in Germany and France, in Emmenegger P. et al. (eds.) The age of dualization: the changing face of inequality in deindustrializing societies, Oxford, Oxford University Press, 100-123.

Kunst B. (2015) Artist at work: proximity of art and capitalism, Winchester, Zero Books.

Laslett B. and Brenner J. (1989) Gender and social reproduction: historical perspectives, Annual Review of Sociology, 15, 381-404.

Lee D. (2015) Internships, workfare, and the cultural industries: a British perspective, Triple C, 13 (2), 459-470.

Lehdonvirta V. (2016) Algorithms that divide and unite: delocalization, identity and collective action in 'microwork', in Flecker J. (ed.) Space, place and global digital work, London, Palgrave Macmillan.

Lewchuk W. (2017) Precarious jobs: where are they, and how do they affect well-being?, The Economic and Labour Relations Review, 28 (3), 402-419.

Lorey I. (2015) State of insecurity: government of the precarious, New York, Verso.

Lübke C. and Erlinghagen M. (2014) Self-perceived job insecurity across Europe over time: does changing context matter?, Journal of European Social Policy, 24 (4), 319-336.

Meagher G. and Szebehely M. (2013) Long-term care in Sweden: trends, actors, and consequences, in Ranci C. and Pavolini E. (eds.) Reforms in long-term care policies in Europe: investigating institutional change and social impacts, New York, Springer, 55-78. 
Moore S. and Newsome K. (2018) Paying for free delivery: dependent self-employment as a measure of precarity in parcel delivery, Work, Employment and Society, 32 (3), 475-492.

Nathan M., Pratt A. and Rincon-Aznar A. (2015) Creative economy employment in the EU and the UK: a comparative analysis, London, NESTA.

OECD (2016) Income inequality remains high in the face of weak recovery. https://www. oecd.org/social/OECD2016-Income-Inequality-Update.pdf

Olsthoorn M. (2014) Measuring precarious employment: a proposal for two indicators of precarious employment based on set-theory and tested with Dutch labor market-data, Social Indicators Research, 119 (1), 421-441.

Parry J. (2005) Care in the community? Gender and the reconfiguration of community work in a post-mining neighbourhood, Sociological Review, 53 (2), 149-166.

Perlin R. (2012) Intern nation: how to earn nothing and learn little in the brave new economy, London, Verso.

Pulignano V. (2018) Precarious work, regime of competition and the case of Europe, in Kalleberg A.L. and Vallas S.P. (eds.) Precarious Work, Bingley, Emerald Publishing, 33-60.

Prosser T. (2016) Dualization or liberalization? Investigating precarious work in eight European countries, Work, Employment and Society, 30 (6), 949-965.

Pyöriä P. and Ojala S. (2016) Prekaarin palkkatyön yleisyys: liioitellaanko työelämän epävarmuutta?, Sosiologia, 53 (1), 45-63.

Rubery J. and Grimshaw D. (2016) Precarious work and the commodification of the employment relationship: the case of zero hours in the UK and mini jobs in Germany, in Bäcker G., Lehndorff S. and Weinkopf C. (eds.) Den arbeitsmarkt verstehen, um ihn zu gestalten, Wiesbaden, Springer, 239-254.

Rubery J., Grimshaw D., Keizer A. and Johnson M. (2018) Challenges and contradictions in the 'normalising' of precarious work, Work, Employment and Society, 32 (3), 509-527.

Saundry R., Stuart M. and Antcliff V. (2006) 'It's more than who you know': networks and trade unions in the audio-visual industries, Human Resource Management Journal, 16 (4), 376-392.

Saundry R., Stuart M. and Antcliff V. (2007) Broadcasting discontent: freelancers, trade unions and the Internet, New Technology, Work and Employment, 22 (2), 178-191.

Schwartz D. (2018) Embedded in the crowd: creative freelancers, crowdsourced work, and occupational community, Work and Occupations, 45 (3), 247-282.

Siebert S. and Wilson F. (2013) All work and no pay: consequences of unpaid work experience in the creative industries, Work, Employment and Society, 27 (4), 711-721.

Simms M. (2017) Unions and job quality in the UK: extending interest representation within regulation institutions, Work and Occupations, 44 (1), 47-67.

Simms M., Eversberg D., Dupuy C. and Hipp L. (2018) Organizing young workers under precarious conditions: what hinders or facilitates union success, Work and Occupations, 45 (4), 420-450.

Simonazzi A. (2009) Care regimes and national employment models, Cambridge Journal of Economics, 33 (2), 211-232.

Sirovátka T. and Greve B. (eds.) (2015) Innovation in social services: the public-private mix in service provision, fiscal policy and employment, Aldershot, Ashgate.

Streeck W. (2009) Re-forming capitalism: institutional change in the German political economy, New York, Oxford University Press.

Streeck W. (2016) How will capitalism end? Essays on a failing system, London, Verso.

Szebehely M., Stranz A. and Strandell R. (2017) Vem ska arbeta i framtidens äldreomsorg? [Who will work in eldercare in the future?], Working Paper/Department of Social Work 2017:1, Stockholm, Stockholm University. 
Szebehely M. and Trydegård G.-B. (2011) Home care in Sweden: a universal model in transition, Health and Social Care in the community, 20 (3), 300-309.

Tapia M. and Turner L. (2018) Renewed activism for the labor movement: the urgency of young worker engagement, Work and Occupations, 45 (4), 391-419.

Thelen K. (2014) Varieties of liberalization and the new politics of social solidarity, Cambridge, Cambridge University Press.

Treas J. and Widmer E.D. (2000) Married women's employment over the life course: attitudes in cross-national perspective, Social Forces, 78 (4), 1409-1436.

Townley B. and Beech N. (eds.) (2009) Managing creativity: exploring the paradox Cambridge, Cambridge University Press.

Vallas S.P. (2012) Work: a critique, Cambridge, Polity.

Van Aerden K., Moors G., Levecque K. and Vanroelen C. (2014) Measuring employment arrangements in the European labour force: a typological approach, Social Indicators Research, 116 (3), 771-791.

Van Assche A., Laermans R. and Pewny K. (2018) Artistic labor and modes of precarity: lessons from the Brussels contemporary dance scene (in review).

Van Assche A. and Laermans R. (2016) Artistic labor and modes of precarity lessons from the Brussels contemporary dance scene, Paper presented at the 9th Midterm Conference of the Research Network Sociology of the Arts of the European Sociological Association: Arts and creativity: working on identity and difference, Porto, Portugal, 8-10 September 2016.

Umney C. (2016) The labour market for jazz musicians in Paris and London: formal regulation and informal norms, Human Relations, 69 (3), 711-729.

Weil D. (2014) The fissured workplace: why work became so bad for so many and what can be done to improve it, Cambridge, Harvard University Press.

Wood A.J., Graham M., Lehdonvirta V. and Hjorth I. (2018) Good gig, bad gig: autonomy and algorithmic control in the global gig economy, Work, Employment and Society. https:// journals.sagepub.com/doi/10.1177/0950017018785616

Zukin S. and Papadantonakis M. (2017) Hackathons as co-optation ritual: socializing workers and institutionalizing innovation in the "new" economy, in Kalleberg A.L. and Vallas S.P. (eds.) Precarious Work, Bingley, Emerald Publishing, 157-181.

Zysman J. and Newman A. (eds.) (2006) How revolutionary was the digital revolution? National responses, market transitions, and global technology, Stanford, Stanford University Press. 